\title{
The Significance of the Joint University Libraries
}

\author{
Dean Wilson, of the Graduate Library \\ School of the University of Chicago, pre- \\ sented this paper at the dedication of the \\ Joint University Library, Nashville, Ten- \\ nessee, December 6, I94I.
}

$\mathrm{T}$ HE DEDICATION of a new library building to serve the students and scholars of a great modern university is always an occasion for special ceremonial. And well it should be. It marks the addition to the varied resources of the university of a new, carefully planned building set apart to aid the university in achieving the ends for which the university has been established and maintained by society. It tremendously reinforces the university's efforts to conserve and revitalize knowledge and ideas from the past, to discover new knowledge and develop new ideas, and to pass this cumulated heritage on to succeeding generations through instruction, publication, and public service. It signalizes the supplementation of old forces and the release of new forces within society which inevitably contribute to its increasing understanding and cultural enrichment.

The dedication of the Joint Library of Vanderbilt University, George Peabody College for Teachers, and Scarritt College for Christian Workers shares this general significance with the dedication of all university libraries. But it does not stop there. It does something more. It has a significance peculiar to itself which derives from other causes than those just mentioned. This significance is at once so great and so unusual that we may do well to take time to analyze it in order that we may better understand just what it is.

First of all, the dedication of this building marks the culmination of a full decade of institutional planning by educational foundations, higher institutions of education, and libraries which has resulted in a clearly defined, purposeful program of educational cooperation. It makes concrete in brick and stone a type of planning of which there have been all too few examples in the past and of which it may be hoped there will be an increasing number in the future. Here the normal loyalties and rivalries of three institutions which usually tend to keep institutions apart have given place to the united consideration of means for enriching teaching and research insofar as this can be accomplished by the elimination of duplication in teaching at the undergraduate level, by the concentration of facilities and resources in the fields of graduate and professional study, and by the provision and support of a great joint library. Here is an enterprise involving three student bodies, three faculties, three libraries, and two educational foundations, which brings them all together in a unified program of education, of which this splendid new library building is the visible 
symbol. In these respects, the dedication of this building, to the usefulness and beauty of which librarians, builder, and architect have contributed, stands out as an instance of a new and significant type of educational statesmanship.

This dedication is significant for a second reason. It marks the emergence of a new type of educational administrative device. Prior to the 1930's, the attitudes of American institutions of higher education were characterized by rugged individualism. Funds for higher education were relatively abundant in the 1920's, and every university and college looked to the day when it would be bigger and richer and capable of outdistancing all its competitors. University libraries shared this spirit and attempted to make themselves self-sufficient. In the two decades of the 1920's and I930's, while they more than doubled their holdings, they constantly bid against one another for rare materials and thereby increased the cost to themselves and to other libraries alike. They, and the boards of control of the institutions of which they were parts, did not set their legal staffs to work to devise means by which they could cooperate. The legal instrument, however, by means of which this joint library has been brought into being, is a newly conceived type of educational document. Although cooperative agreements among educational institutions and libraries have existed heretofore, the educational authorities and legal staffs who drafted this instrument did not find an educational model ready at hand. It is a document that renounces competition among institutions and libraries as a way of life and sets up in its stead a plan of cooperation for common benefits. It calls into being what, for lack of a better term, may be called an educa- tional holding company organized not for financial profit but for the continuous cultivation of men's minds. It has already been widely studied. Principles very similar to those which it embraces have been applied by the libraries of Harvard University and other New England institutions in providing a common storage library for little-used books. It will continue to be studied by other colleges and universities which seriously seek to maintain and improve library facilities for instruction and research under the steadily increasing financial difficulties of the time.

\section{Program of Curriculum Revision}

The arrangement by which the joint library was brought into being is significant for another reason. It was worked out as a part of a program of curriculum revision in which not only the curriculums of all three institutions were considered together but the demands which the curriculums made upon the libraries of all three institutions were also considered. This again is an instance of an educational procedure which has likewise been all too infrequently employed by institutions when they have been involved in curriculum revision. Many institutions develop new plans for improving instruction or for carrying on investigation in new fields without including their libraries in the planning, and then are surprised when the effectiveness of the program is not so great as they had thought it should be, because proper library provision had not been made in the planning. It is only recently that a certain college president was heard to remark with evident, but illfounded pride, that he had just finished putting through an extensive curriculum revision in his institution, that next year he was going to concentrate his attention 
on the development of facilities for the study of art, and that after he had completed these programs he was going to do something about the library! It did not seem to occur to him that unless these undertakings were properly supported with library resources and integrated with intelligent library use, the results he expected from them could not be achieved. The success of the survey courses at the University of Chicago and of the house plan and tutorial instruction at Harvard is attributable in part to the fact that both institutions devoted as much consideration to the selection and provision of the library materials which were to support the programs as they devoted to their organization and general content.

\section{Staffs United}

Here on these campuses a significant procedure was followed. The instructional and research staffs united to consider the elimination of competition and duplication of effort at the undergraduate level in order that work at the graduate and professional levels might be increased. They were conscious of the fact that no effective program of collaboration in these fields could be worked out which failed to include within it a plan of library development as well. Consequently, plans for providing library resources to support specialization and research in desired fields were made an integral part of the whole program. All of the planning went forward together, and the provision for this new building, for securing additional endowment for library purposes, and for increased library operating funds was, in fact, precedent to other developments which may now be expected to follow.

This is the kind of curriculum planning involving the careful integration of cur- riculum and library use, which, if followed from the elementary school, through high school, college, and university, will tremendously increase the effectiveness of American teaching and research.

\section{Role of Library in Higher Education}

On a number of occasions I have spoken of the role of the library in higher education and especially in higher education in the South where library resources have not been nearly so abundant as they have been in other parts of the nation. This audience knows the nature of the limitations which result from this lack and their effect upon productive scholarship. It knows that most Southern universities have been unable to undertake graduate work in many departments leading to the doctorate because essential library resources are lacking. It knows that thousands of graduate students have been lost to the schools and colleges and the business and professional life of the South because they went elsewhere for graduate training, and, after completing it, did not return to the South. It knows that the training of thousands of other students who were unable to use such materials in Southern universities has been less effective than it should be because of this lack. The dedication of this new library is of the greatest significance to higher education in this region because it marks the firm establishment of a new concentration of library resources upon which distinctive graduate work can be confidently based. With this concentration of four hundred thousand volumes, supplemented by the services of union catalogs and microphotography laboratories, which bring the total library resources of the city to more than eight hundred thousand volumes, students and scholars in Nashville can go abou their daily work 
with new confidence. Nashville in a truer sense than ever before becomes a university center which not only can support the work of scholars here, but can make more fruitful the work of scholars on all the university campuses of the South. This installation of new resources not only reinforces work here but adds to the combined resources of all the centers of learning stretching from the nation's capital to the Mexican border.

\section{Contribution to Resources for Research}

A further significance of the dedication is to be seen in the contribution which the joint library makes to the total resources for research of the nation. In the official year $1935-36$ of the American Library Association the status of the Committee on Resources of American Libraries was changed from that of a committee to that of a board, with enlarged powers, and a committee on microphotography was established. Since that date a conscious, wellconceived library program has been developed which has had two major objectives. The first has been the location and description of library materials essential to research. The second has been the increased provision of bibliographical apparatus and films for the use of scholars. Librarians and scholars in all parts of the nation have participated in this undertaking and have had the satisfaction of witnessing its successful development. Union catalogs and bibliographical apparatus have been provided in a number of the major libraries in various regions of the country for the location of research materials. The resources of the Union Cata$\log$ of the Library of Congress have been greatly extended by the inclusion of cards from hundreds of libraries and regional union catalogs. It has, as a result, become the ultimate source to which the scholar, wherever located, may confidently look for bibliographical assistance. A number of notable microphotography laboratories have been established in university and research libraries for the reproduction of rare yet indispensable materials. Machines for the satisfactory reading of films have been developed and are to be found in reference rooms and special collections on campuses everywhere. The resources of a number of major research libraries have been systematically described by subject fields and significant titles through library surveys and other publications. A conference of national scope and attended by librarians, officers of universities, and members of learned societies has been held, which dealt with many phases of library cooperation and specialization. The $\mathrm{Li}$ brary of Congress, through the aid of an educational foundation, has set up a temporary Division of Library Cooperation, by means of which further aid to libraries and scholars is anticipated. A report growing out of a nationwide study of union catalogs and describing the nature of their services is now in press, and two editions of a publication describing the resources of libraries and special collections useful in national defense have recently been made available to the public. Altogether, this program is one of the most notable undertakings in America for the advancement of scholarship and it is one in which the librarians of Southern universities have played a leading role. In this movement the joint library, through its librarian and the librarians of Nashville, has taken a conspicuous part. Through their planning with the instructional and research staffs here, and their cooperation with librarians throughout the country, they have aided these three in- 
stitutions to make a splendid contribution to the human and cultural resources of the nation.

\section{Will Attract Other Gifts}

A sixth significance of this dedication is to be found in the fact, for it is a wellproven fact, that this concentration of library buildings, resources, and staffs will attract other collections and gifts devoted to library service. Great libraries attract great gifts. Individual friends of the library, organized friends of the library, alumni, and nonalumni, will inevitably be impressed with the concentration and multiplication of resources represented here, and when seeking ways through which to contribute to educational effectiveness will find in this library the means which will aid them to this end. Splendid evidence of this fact is already here. I have spoken of the educational foundations, of the three institutions, and of the three libraries which have participated in bringing this new resource of learning and investigation into being. But I am not unmindful of the fact that supplementing their effort has been the significant support of students and members of these faculties and of men and women of this city, of this state, and of the nation, who, through their interest and gifts have made this library their very own. Without their aid, this building would not have been possible. They will be succeeded tomorrow, and in the lengthening future, by others who will add to what they have so generously helped to begin.

The final significance which may be associated with this dedication is the part which this new library should play in preparing teachers and librarians for more effective teaching and research. In I93 I in a paper which $I$ read before the Ameri- can Library Association at Yale entitled "The Emergence of the College Library," I presented evidence which seemed to me conclusive that the college library was then moving forward into new areas of usefulness in the field of higher education. The evidence seemed to be of many kinds. New curriculums were being established here and there which called for greater use of library service. Libraries were expanding their book collections and adding to their staffs personnel imbued with new educational ideals. Books and articles by college librarians, college presidents, and officers of educational foundations dealt with the larger role which the college library should play in the educational process. The college library in reality could be said to be entering upon a new period of usefulness in which teaching with books was becoming an important method of teaching.

\section{Similar Movement in Other Libraries}

Today it seems to me that a similar movement can be detected in other types of libraries. From the elementary school through the junior college, similar stirrings are to be noted. Better library quarters have been provided; more books have been purchased; more periodicals have been placed on the shelves; more radios, records, slides, and films have been secured; more librarians have been put into service; more superintendents, principals, and teachers have gained some understanding of the role of the library in teaching; and more school boards and state legislatures have provided increased funds for library purposes in many types of libraries.

This situation presents one of the greatest challenges to the institutions located on these campuses. These institutions, in- 
cluding as they do a university, a teachers college, a school for the training of librarians, a practice school library for elementary and secondary schools, and a library embodying all the best features of modern library service, have the opportunnity of training prospective teachers and librarians at all levels of education in such a way as to enable them better to integrate library use and teaching than teachers and librarians have been able to in the past, and thereby tremendously increase their educational efficiency. If I am not greatly mistaken, it is just at this point where library use and teaching unite that American education will make its greatest advance in the next decade. Here in the libraries and classrooms of these adjoining campuses, the foundation has been laid for uniting teachers and librarians in a program of training which should make certain that all prospective teachers and educational administrators will understand how to utilize library materials in effective teaching. Unfortunately, many teachers do not know how to do this today. Furthermore, graduate study is generally so preoccupied with specialization and the use of highly specialized source materials that the prospective teacher has little opportunity while working for advanced degrees to become familiar with materials which can be used effectively in teaching at other levels. The foundation has likewise been laid here that should make certain that prospective librarians at all educational levels will understand the educational aims of the institutions which they serve and the best methods by which library materials may be used in their attainment. Fortunately for the improvement of teaching, the institutions which share in the use of the library resources of these campuses likewise share the philoso- phies of education and librarianship which insist upon the combination of these important understandings without which teaching cannot achieve its greatest effect. If those who teach and those who administer libraries here imbue prospective teachers and librarians with these philosophies and send them thus equipped into the schools and colleges of the nation, education will take on a new and fuller meaning.

\section{Forty Years' Development}

Forty years ago this December I wrote my first report as librarian of a neighboring Southern university. In the four decades that have intervened I have constantly studied the growth of libraries in higher institutions of education in this region. I have witnessed the movement for greater library resources, for more ample library support, for more adequate library buildings, go forward. I have seen the book collections reach the first one hundred thousand mark, then the quarter and half million marks. Now two are on the climb to the million mark. I have watched budgets grow to $\$ 10,000$ annually, to $\$ 50,000$, to $\$ 100,000$, and more. I have seen special collections of a few hundred or a few thousand titles become so extensive as to give distinction to any institution which might possess them. I have witnessed from Virginia to Texas the erection of university library buildings that in their organization and size reflect the expanding conception of the importance of library resources and service in higher education. At times this movement has been slow. But at all times it has been forward.

Today as I consider this new achievement, I congratulate you, individually and collectively, who have made this building

(Continued on page 138) 
lem of reducing our expenditures to meet a declining enrolment. Most of us have already cut so deeply that further cuts can be made only by major amputations. We have been spending staggering sums on cataloging our collections and I am inclined to think that our faculties and administrations do not think the money well spent. The arguments we have been using will, I think, be insufficient.

Fifth, it is a commonly heard observation that we librarians resist changes in our technical processes with a fervor that approaches fanaticism. It is my guess that unless we can break ourselves of this rather primitive attitude toward our technical processes, we will lose control of them just as we are losing control of university libraries through our failure to understand that a community of scholars needs a library "of the scholar, by the scholar, and for the scholar."

If my remarks today seem irrelevant to the question, please accept my explanation that these are the implications which I as an administrator of a university library see in the new code. I speak for myself, not for my colleagues.

\section{The Significance of the Joint University Libraries}

(Continued from page 107)

possible. Through the plans which you have perfected and through the building which you have added to the enduring resources of these three institutions, you have made a contribution to the extension and enrichment of education, the full significance of which cannot now be foreseen.

You have placed here at the center of these campuses a library building functionally designed to serve the varied interests of a distinguished community of students and scholars. Rooms for leisure and required reading and for the consultation of periodicals and reference works are available to the undergraduate; carrels in the stacks and special reading rooms are at the disposal of the graduate student ; seminars and studies are set apart for the faculty member; space for bibliographical apparatus, for microphotography, for the exhibition and use of special collections, and for the administration of the library as a whole, rounds out the full complement of the requirements of a modern university library. And all of these essentials have been skilfully organized in a building which in beauty of line and impressiveness of form stands as a symbol of the dignity and worth of learning. These are the obvious results of your conscious collaboration. But what you have so splendidly begun will, I am confident, demonstrate what has so frequently been demonstrated of the work of planners and builders heretofore. It will demonstrate that, splendid as have been your vision and accomplishment, you have actually planned and built better than you knew. 